\title{
SMART INTEGRATION
}

\author{
JERZY KORCZAK*
}

\section{KEYWORDS}

Euroregion, smart administration, agreement, transfrontier nature, cooperation of territorial self-government units

\begin{abstract}
The article is devoted to smart integration taking place on the Polish-German borderland and, more precisely, the border between the Lower Silesian Voivodeship and the Saxony Länder, which, according to the author, is the result of an evolution of forms of transfrontier cooperation of territorial self-government units. It will analyse the conditions for the emergence of forms of cooperation in the transfrontier area and their evolution in European experiences to date and, after 1990, also with the involvement of Polish territorial self-governments.
\end{abstract}

\section{INTRODUCTION}

The idea of independence of the operation of territorial self-government units does not mean autarky or autonomy, as proclaimed by Hans Pagenkopf 'Die Gemeinden der Gegenwart führen kein isoliertes Dasein mehr'. ${ }^{1}$ Similarly, Jan Boć noted that, in conditions of the decentralisation of public administration, as a result of which many very small independent enclaves of territorial selfgovernment arose, a threat arises of the differentiation of the decomposition of

\footnotetext{
* PhD in Law, Professor at the Institute of Administrative Science, Head of the Section of Public Administration System, Faculty of Law, Administration and Economics, University of Wroclaw, jerzy.korczak@uwr.edu.pl

1 Hans Pagenkopf, Kommunalrecht (Bd. 1, Carl Heymanns Verlag KG, 1975) 184
} 
the element integrating intelligence leading to the fact that the same degree of saturation with their smart organisation will not take place in the individual enclaves. If the effect of the territorial self-government units, which are separate, being alone is superimposed on this, in his opinion, 'the separation of territorial self-government units is one of the causes of the unfavourable phenomena of today's frequently pathological phenomena, where everyone, not seeing the control, the regime of the superior entity, is closer to overstepping the limits of morality, reliability, purposefulness, economy, justice, the protection of the public interest, honesty and competence'. ${ }^{2}$

One of the ways of neutralising this threat is the cooperation of territorial self-government units, which became the subject of the first legal regulations as early as in the 19th century. ${ }^{3}$ As these forms developed and the processes of decentralisation of public authority in Europe intensified, on the one hand, the monopoly of the state authorities in establishing international relations was broken, and, on the other hand, the needs and capabilities of the local authorities showed that cooperation in the modern world between individuals and units within their own state is no longer sufficient but needs to extend beyond these borders. The intensifying decentralisation processes and the aim towards forms of borderland cooperation to increase autonomy triggered the initiative for local and regional self-government communities to cooperate.

Whilst Western European municipalities were able to practice such cooperation since the middle of the 20th century, in the case of Polish territorial self-government units, it was only Poland's return to self-governmental Europe initiated by the systemic transformation at the turn of 1989 and 1990 that created opportunities for their participation in forms of municipal cooperation across state borders. ${ }^{4}$ The evolution of these forms is a research issue that is worthy of particular attention, all the more so that the 'Territorial Agenda of the European Union 2020, towards an Inclusive, Smart and Sustainable Europe of Divers Region', which is to be the next stage of European integration, was adopted at the Informal Meeting of Ministers Responsible for Spatial Planning and Territorial Development on 19 May 2011 in Gödöllö in Hungary. In point 12, the ministers who attended expressed the view that 'Territories with common potentials or

2 Jan Boć, ‘Administracja publiczna jako organizacja inteligentna' in J Boć (ed), Administracja publiczna (Kolonia Limited 2003) 362-363

3 More on this subject in Jerzy Korczak, 'Ewolucja form współdziałania jednostek samorządu terytorialnego na forum międzynarodowym' in Janusz Sługocki (ed), Samorzad terytorialny w Polsce i Europie. Doświadczenia i dylematy dalszego rozwoju (Kujawy and Pomorze University in Bydgoszcz 2009) 331

4 cfJerzy Korczak and Konrad Nowacki, 'Die kommunalen Verbänden und ihre Zusammenarbeit unter Berücksichtigung der grenzüberschreitenden Fragen' in Eike Albrecht and Konrad Nowacki (eds), Die grenzüberschreitende Beteiligung der Öffentlichkeit und der Behörden in Deutschland und Polen (LexxionVerlagsgesellschaft mBh, 2006) 172 
challenges can collaborate in finding common solutions and utilise their territorial potential by sharing experience. Territories with complementary potentials, often neighbouring, can join forces and explore their comparative advantages together creating additional development potential', which means that 'The better use of territory can contribute positively to the development of economies; fair access to services of general interest; infrastructure and public goods; and wise management of natural and cultural asset' (point 13). ${ }^{5}$

\section{Experience of Transfrontier Cooperation of European Self- GOVERNMENTS}

As already noted, the political division of Europe after the Second World War has meant that these experiences are very different, because, in the so-called Eastern Bloc, the hypocrisy of the party authorities proclaiming slogans about friendship and cooperation between nations did not translate into any relations at local level, whilst the Schuman Plan caused further-reaching consequences than the authors themselves expected. ${ }^{6}$ The municipalities of Western Europe have been practicing cooperation solutions since the early 1950s. The first partnership between cities, which arose in 1950, was the German-French partnership between Ludwigshafen and Montbéliard.

Compared with numerous partnerships, better organised and formalised forms of cooperation started to arise in the form of associations and municipal agreements, taking on the name of Euroregions. The Euregio of 1958, established by Enschede and Granau, Rhein-Waal in 1973, the Euregio Maas-Rhein 1974 (Aachen, Lüttich and Maastricht), Ems Dollart Region (EDR - the Dutch provinces of Griningen and Drenthe), the German Friesland, Ostfriesland, Emsland and Cloppenburg) from 1977 are amongst the first, best-known European transfrontier regions. Seventy years after the emergence of the Euregio, there are now more than 200 Euroregions. $^{7}$

5 European Union, 'Territorial Agenda of the European Union 2020: Towards an Inclusive, Smart and Sustainable Europe of Diverse Regions' (Hungary, 19 May 2011) <www.nweurope. eu/media/1216/territorial_agenda_2020.pdf $>$ accessed 20 March 2018

6 During the Workshop Open Days: EGTC: 'Learning from experience' 8 October 2008 in Vienna, Johannes Meier, Chairperson of the 'EGTC-AAP Statute' Expert Group, mentioned that attention was drawn in 1978, at the inauguration of the Adriatic Group (Alps-Adriatic Working Community) in Venice, to the limitations on the possibility of regional cooperation with countries from behind the 'Iron Curtain', which only passed after the collapse of this system and, today, Slovenia, Croatia (1992) and Hungary (1993) can belong to it. <www.cor. europa.eu/COR_cms/ui> accessed 9 February 2009

7 Such a number was stated by Dumitru-Tudor Jijie, Director of the Euroregion Association Siret-Prut-Dniester from Romania, during the debate named 'Euroregions - A Way to 
The development of these relationships was enabled by the appropriate regulations of international law. The general legal framework for transfrontier cooperation is formed by the documents adopted by the Council of Europe and the Community authorities since the 1950s. The first such document expressing the desire of border regions to cooperate was Resolution 15 of the Conference of European Local Authorities on the integration of the border regions of 1969. In turn, in Resolution 74 of the 8th Committee of Ministers of 27 February 1974 on the cooperation of local units in border regions, the Committee supported international cooperation, particularly bilateral cooperation in this field. An important step towards creating a legal basis was Recommendation 784 of the Parliamentary Assembly of 28 June 1975, in which attention was drawn to the need to draft a framework convention on European borderland cooperation. ${ }^{8}$ The Council of Europe adopted the European Charter for Border Regions ${ }^{9}$ on 20 November 1981, which changed its name to the European Charter of Border and Transfrontier Regions ${ }^{10}$ on 1 December 1995, although it is not actually an act of international law but purely a declaration of cooperation and a unique kind of code of good practice in transfrontier cooperation.

Over time, limitations started to be felt with regard to the functionality of the forms of cooperation applied to date, which inspired the EU authorities to seek forms of cooperation enabling the creation of an international public law entity that can take over their tasks, receive components of their property and create organisational units. This became possible in 2006 as a result of the Regulation of the European Parliament and of the EU Council introducing the European Grouping of Territorial Cooperation (EGTC). ${ }^{11}$ As the regulation requires application to national law, the process of first adopting and then creating individual EGTCs is continuing. Sixty-five EGTCs with the involvement of entities from 20 countries arose in Europe by the end of 2016; the majority (56) being of a transfrontier nature, although there is one with the involvement of a

Stimulate Social and Economic Cooperation' during the 10th Europe-Ukraine Forum, held on 27-28 January 2017 in Rzeszów <http://www.forum-ekonomiczne.pl/debata-euroregionysposob-na-ozywienie-wspolpracy-spolecznej-i-gospodarczej-w-ramach-x-forum-europaukraina/> accessed 20 May 2018

8 The European Outline Convention on Cross-Border Cooperation between Territorial Communities or Authorities - also known as the Madrid Convention - adopted by the Council of Europe on 21 May 1980, was signed by Poland in Warsaw on 10 March 1993 and ratified by a government declaration of 1 April 1993 (Journal of Laws No 16, items 267 and 268)

9 This took place in the EUREGIO already mentioned, the first Euroregion in history on the German-Dutch border

10 This took place in Szczecin in the 'Pomerania' Euroregion at the meeting of the Association of European Border Regions of the AEBR established in 1971 at the EUREGIO headquarters

11 Regulation (EC) 1082/2006 of the European Parliament and of the Council of 5 July 2006 on a European grouping of territorial cooperation (EGTC) (OJ EU L210/19) 
city from Palestine. Most of the groups were established in Hungary and France (24 each), Slovakia (17) and Spain (16), whereas the number of groups in the remaining countries ranges from 1 to $9 .^{12}$

\section{The Notion of The Transfrontier Nature and Transfrontier Cooperation from the Point of View of Integration}

The notion of a transfrontier nature is rather complex because of the lack of uniformity of terminology used in legislation, the legal doctrine ${ }^{13}$ and practice in handling transfrontier cooperation. Article 2 (1) of the Madrid Convention adopted a very broad definition of transfrontier cooperation as any concerted action designed to reinforce and foster neighbourly relations between territorial communities or authorities within the jurisdiction of two or more contracting parties and the conclusion of any agreement and arrangement necessary for this purpose. Polish law has no normative term for 'transfrontier cooperation', ${ }^{14}$ or all the more so a legal definition, because the provisions of the constitution and self-governmental systemic acts, which will be the subject of further analysis in the context of the legal grounds for municipal cooperation in the international, especially transfrontier dimension, do not use the term 'transfrontier cooperation'.

Therefore, 'transfrontier cooperation' is a legal term used in the legal doctrine and documents related to municipal cooperation, but with very different semantic contexts. Renata Kusiak-Winter very comprehensively analysed these contexts using mainly publications in German and Polish, as well as the terminology of German Länder law acts, giving examples of terms such as 'transfrontier cooperation', 'borderland cooperation', and also 'international cooperation' and even 'foreign cooperation', actually referring to the transfrontier spatial

12 Bulletin of the Polish Institute of International Affairs, 20 June 2017, No 59 (1501)

13 To Stefan Czarnów, a transfrontier nature should be understood to mean adjacent borderlands from several countries (eadem, 'Niektóre aspekty prawne współpracy transgranicznej i euroregionów' (1997) 10 Państwo i Prawo 55), whereas to Stanisław Malarski transfrontier cooperation is synonymous with borderland cooperation (eadem, Regiony i euroregiony: zagadnienia organizacyjne, prawne, administracyjne (Wydawnictwa WSZiA 2003) 188

14 Renata Kusiak-Winter, Wspótpraca transgraniczna Polski $i$ Niemiec. Studium administracyjnoprawne (Wroclaw: Prawnicza i Ekonomiczna Biblioteka Cyfrowa 2011) 24 recalls that this term appeared in Polish law for the first time in art 10, para 1 of the Act on field bodies of general government administration of 22 March 1990 (Journal of Laws No 106 , item 498), where the voivod was authorised for handling transfrontier cooperation, which ceased to apply after the administrative reform of 1998. Despite setting tasks for the voivod regarding cooperation with the competent state authorities of other states, the currently applicable provision of art 23, para 1 item 2 of the Act on the voivod and government administration in the voivodeship of 23 January 2009 (Journal of Laws of 2017, item 2234, as amended) does not mention transfrontier cooperation 
dimension. ${ }^{15}$ For these reasons, she proposed certain criteria, the use of which enables the definition of given municipal cooperation as 'transfrontier cooperation'. First is the subjective scope, namely, its conduct by territorial selfgovernment units, most frequently by municipalities, although in practice also by their associations or other institutional forms of cooperation. Second is the objective scope, which she defined as 'a task, the joint performance of which arises from either the location of the partners in a specific proximity to each other, or is determined by an attempt to overcome the negative effects of the consequences of the border ...'. Third is the spatial scope related to the location of the participants of the cooperation with respect to the border, therefore, belonging to a different state from them; although in the case of most partners of such cooperation (obviously remembering the eastern border), these are still internal borders within the area of the EU. ${ }^{16}$

\section{Legal Grounds for Transfrontier CoOperation Under Polish LaW}

The ability to establish cooperation on an international forum, including transfrontier cooperation for territorial self-government units that are public law entities in a state of law, requires appropriate regulation. It is based on the general principles of cooperation in the forms provided for by law, which in Poland, in most cases, are voluntary, as none of the systemic laws on Polish territorial selfgovernment required taking up forms of cooperation (only Article 64, para. 4 of the Act on municipal self-government ${ }^{17}$ provides for the ability to impose an obligation to establish an inter-municipal association by law, of which, however, so far there are none, except for the Warsaw episode from 1990-1998 ${ }^{18}$ ); however, such requirements can be found in substantive law. ${ }^{19}$ Systemic acts explicitly define the basic forms of cooperation of territorial self-government units, although

15

16

17

18

19

Kusiak-Winter (n 14) 19-31

ibid $37-42$

The Act on municipal self-government of 8 March 1990 (Journal of Laws of 2018, item 994)

This applies to the Acts on the system of the Capital City of Warsaw of 18 May 1990 (Journal of Laws No 34, item 200, as amended) and of 25 March 1994 (Journal of Laws No 48, item 195 , as amended), which gave the city the status of a union of so-called Warsaw municipalities

The argument of precisely such an interpretation of art 3 of the Act on spa treatment, health resorts and areas of spa protection and on spa municipalities of 28 July 2005 (Journal of Laws of 2017, item 1056, as amended) is formulated in the legal doctrine with regard to inferring from it the obligation to form a union if the conditions described in that regulation are satisfied - as in Paulina Łazutka, 'Współdziałanie gmin uzdrowiskowych w formie związku celowego jako przykład wielopostaciowości form wykonywania zadań z zakresu administracji publicznej' in E Pierzchała (eds), Wielopostaciowość wspótczesnej administracji publicznej. 
two of them, on municipal self-government (Articles 64, 74 and 84 of the Act on municipal self-government) and county self-government (Article 65 and Articles 73-75 of the Act on county self-government ${ }^{20}$ ), list three forms, whilst the Act on the voivodeship self-government only lists two (Article 8, para. 2 and Article 8b of the Act on the voivodeship self-government $\left.{ }^{21}\right)$. Therefore, in accordance with the applicable provisions of the law, there can be talk of agreements between territorial self-government units, unions of territorial self-government units and associations of territorial self-government units.

These forms can be referred to cooperation of an international dimension and it should be emphasised that, at the time of the establishment of the selfgoverning municipality on 27 May 1990, there were no legal grounds enabling a Polish municipality to establish any cooperation with a municipality or other municipal entity from beyond the state borders. First, there were no grounds in national law, because the systemic act did not refer to this level of municipal cooperation, whereas, second, there were no grounds in international law because of a lack of international agreements involving Poland, which provided for cooperation. It was only the signature of the regional, border and transfrontier cooperation agreements (this was precisely where the terminological inconsistency previously mentioned appeared) with all the neighbouring countries, as well as with other European countries that made this possible. ${ }^{22}$ Despite the previously mentioned ratification of the Madrid Convention in 1993, there were no regulations of national law allowing for the establishment of the forms of transfrontier cooperation provided for in it.

The adoption in 1997 of the Constitution of the Republic of Poland ${ }^{23}$ significantly changed this legal situation because of Article 172, which awarded territorial self-government units the right to associate, including join international associations of local and regional communities, as well as cooperate with these communities. However, paragraph 3 of this provision referred to the acts specifying the principles on which territorial self-government units can take advantage of these rights, which did not exist at the time it entered into force. The first self-government act, which referred to the matter of international cooperation was the Act on the voivodeship self-government, which devoted a separate chapter 6 to the international cooperation of the voivodeship, providing in it for

Publikacja poświęcona pamięci Pana Profesora Jana Bocia (2018) XVI/1/1 Opolskie Studia Administracyjno-Prawne 120-125

20 The Act on county self-government of 5 June 1998 (Journal of Laws of 2018, item 995)

21 The Act on voivodship self-government of 5 June 1998 (Journal of Laws of 2018, item 913)

22 A description of this process and a list of these agreements can be found in Korczak and Nowacki (n 4) 178-181

23 The Constitution of the Republic of Poland of 2 April 1997 (Journal of Laws No 78, item 483, as amended) 
the adoption of 'Priorities of the voivodeship's foreign cooperation', setting the geographical priorities of cooperation, its objectives and intentions regarding activity in international regional associations. ${ }^{24}$ The gaps in the law were finally filled in 2000 with the regulation of the principles of territorial self-government units joining international associations of local and regional communities, ${ }^{25}$ which made appropriate changes in the other, namely, the municipal and the county self-government acts, currently allowing every Polish territorial selfgovernment unit to establish cooperation of various types with territorial selfgovernment units of other countries and their associations of an international nature. Finally, the EGTCs mentioned above were applied to Polish law in 2008. ${ }^{26}$

\section{Experiences of Polish Self-governments in Cooperation BeTWEen SELF-governMENTS IN THE INTERNATIONAL Dimension}

In contrast with the experiences of Western European self-governments in Poland, the process of taking up international cooperation was initiated much later and proceeded in a more complex manner. This ignores the period of the socialist state mentioned at the beginning when, in order to confirm the so-called brotherly relations between the countries from the camp of the people's democratic state, the so-called partnerships were established between brotherly cities (rather not rural municipalities). They were not voluntary; they were not actually implemented and rather only served the purpose of maintaining political contacts of local representatives of the authorities of that time. Therefore, it was only the revival of territorial self-government in 1990 that means there can be talk of cooperation between Polish municipalities and the municipalities of other countries and their involvement in organised forms of international cooperation. However, the difficulty was the already mentioned lack of legal grounds for such actions, which was pointed out from the beginning in the self-government literature, simultaneously indicating the obvious benefits that the resurgent Polish

24 More on this topic Jerzy Korczak, 'Priorytety współpracy zagranicznej województwa jako akt regionalnej polityki zagranicznej' in Seminar Regiony — między państwem a Europa. Modele porównawcze i perspektywy rozwoju (Chamber of Crafts and Small- and MediumSized Enterprises in Katowice, Katowice 2009) 48-56

25 The Act on the principles of accession of territorial self-government units to international associations of local and regional communities of 15 September 2000 (Journal of Laws No 91, item 1009, as amended)

26 The Act on the European grouping of territorial cooperation of 7 November 2008 (Journal of Laws No 218, item 1390, as amended) 
self-government could gain through contacts with the self-governments of Western European countries, especially the neighbouring countries. ${ }^{27}$

Given the lack of regulations in Polish law, the legal forms of transfrontier cooperation assumed the form of partnership agreements concluded between individual Polish and, for instance, German municipalities after obtaining the approval of the minister of foreign affairs each time.$^{28}$ Only bilateral international agreements concluded in the first half of the 1990s began to create a legal framework for this cooperation, extending beyond ordinary partnership agreements. The county and voivodeship self-governments, which were established, started to take up cooperation after 1999 as a result of the administrative reform, which means that the number of partnerships (which, as a matter of interest, were not always registered and therefore the data is estimated) has reached many thousands, as almost all of the 2,478 municipalities, all of the 314 counties and all of the 16 voivodeships have concluded several or a dozen or so partnership agreements with their counterparts in countries from many continents.

First of all, the Polish municipalities started to co-create Euroregions with the municipalities of countries bordering with Poland, taking advantage of the solutions previously described from the German-Dutch, German-French and other border regions. The first Euroregion with the involvement of Polish municipalities is 'Neisse-Nisa-Nysa' Euroregion, which was established on 21 December 1991. Its establishment was initiated by the German party in January 1991 by holding interviews in Brussels and Luxembourg in order to gain the approval of the EU and UNESCO authorities. Work started in 1991 on the establishment of the 'Spree-Neisse-Bober' Euroregion (1993), 'Pro EuropaViadrina' (1993), the Carpathian Euroregion (1993), the 'Bug' Euroregion (1995), the 'Tatras' Euroregion (1996) and the 'Praděd' Euroregion (1996). Each of them proves that integration processes sometimes lasted several years ('Bug' 4 years, and 'Tatras' and 'Praděd' as long as 5 years), which is evidence of not only the difficulties arising from problems of a legal nature (as already mentioned) but also about communication problems in overcoming a certain mistrust between representatives of municipalities, which ultimately entered the Euroregion. In addition, the memberships of the initiators and ultimate members of the Euroregion were changing. ${ }^{29}$ The 'Pomerania' (1995), 'Galciensis' (1996), 'Neman' (1997), 'Baltic' (1998), 'Cieszyn Silesia' (1998), 'Silesia' (1998), 'Beskydy Mountains'

27 Paweł Czechowski and Zygmunt Niewiadomski, 'Administracyjno-prawne przesłanki komunalnej współpracy przygranicznej w Republiką Federalną Niemiec’ (1992) 16(1-2) Człowiek i Środowisko 76-77

28 ibid 78

29 More on the complexity of these processes, as well as organisational structures, the core activities and achievements of all Euroregions with the involvement of Polish selfgovernments, Korczak and Nowacki (n 4) 181-192 
(2000), 'Dobrava' (2001), 'Białowieża Forest' (2002) and 'Łyna-Ława' (2004) Euroregions were established in the following years. ${ }^{30}$

The organisational constraints appearing in the activities of the Euroregions as well as other difficulties in their use for the constantly increasing needs of the border regions ${ }^{31}$ have encouraged the search for new forms of cooperation, which was already addressed by the initiative of the European Commission and the European Parliament of 2006. The Polish self-governments started to set up EGTCs with their involvement almost immediately after the adoption of the Act of 2008 mentioned above. According to the register kept by the minister responsible for foreign affairs, ${ }^{32}$ EGTC TRITIA $z$ o.o. and EGTC TATRY z o.o. were registered in 2013, Central European Transport Corridor European Grouping of Territorial Cooperation Limited Liability Company in 2014 and EUWT NOVUM z o.o. in 2015.

\section{Lower Silesian-Saxony Smart Integration, Essence, Assumptions, ACTIVITIES}

This process of the development of legal forms and experience in the cooperation of Polish territorial self-government units internationally leads to the conclusion that neither are the forms used to date sufficient for the ever newer phenomena in the area of public administration nor are the initiatives taken by the municipalities, counties and voivodeships with the self-government units of other countries in establishing cooperation always effective. For example, after a period of reasonably active contacts, the numerous partnerships between Polish and German municipalities often become limited or even end, which is frequently a result of personal reasons, for example, the initiators and animators of these contacts leave active self-government activities, or newly elected members of the

30 According to Jerzy P Gwizdala, 'Euroregiony jako forma współpracy transgranicznej w Europie' Zeszyty Naukowe Uniwersytetu Szczecińskiego No 855, (2015) 74 (2) Finanse, Rynki Finansowe, Ubezpieczenie 455-456 the functions of 16 out of 17 Euroregions that were created and the total area covered by transfrontier cooperation in this form cover more than $51 \%$ of the area of the country. Agnieszka Stachura and Małgorzata Sikora-Gaca, 'Działalność i zróżnicowanie euroregionów na terenie Polski "Studia Gdańskie"' (2015) XI Wizje i rzeczywistość 129-148 differentiate between regional ('Nemunas', 'Bug', 'Baltic' and the 'Carathian' Euroregion) and local Euroregions, as well as Euroregions consisting of units and those formed from their organisational forms (agreements, associations, etc.)

Bogdan Kościuch and Anna Poźniak, 'Euroregiony a współpraca zagraniczna jednostek samorządu terytorialnego' (2012) 12 Białostockie Studia Prawnicze 63-64, write about these barriers and attempts to eliminate them

32 In accordance with the regulation of the Minister of Foreign Affairs of 9 February 2016 on the Register of European Groupings of Territorial Cooperation (Journal of Laws, item 199) and the previously applicable regulation of 17 June 2009 (Journal of Laws No 105, item. 875) 
bodies have a different political orientation that does not support these specific partnerships. Likewise, amongst the more advanced forms, such as Euroregions, ineffective activities sometimes take place, which is best demonstrated by the case of the Dobrava Euroregion, which was established on 25 January 2001 with the involvement of the Wałbrzyski, Świdnicki and Dzierżoniowski counties, as well as their municipalities, namely Głuszyca, Mieroszów and Walim, the town of Jedlin Zdrój and, additionally, the PRO-EURO Regional Association of Social Initiatives from Wałbrzych and, on the Czech side, the town of Meziměsti, which was formally dissolved in 2004 because the members failed to take up activities. ${ }^{33}$

From 2002, the annual announcements of the minister responsible for administration ${ }^{34}$ contain a list of territorial self-government units that have left international associations of local and regional communities; for instance, Lower Silesia left the 'Dolny Śląsk w Unii Europejskiej' Association ${ }^{35}$ and the Assembly of European Regions -AER..$^{36}$ The reasons for these decisions are obviously very diversified matter, but arguments frequently appear in the justifications of the decisions regarding the exhaustion of the objectives of belonging or the lack of real possibilities of their implementation or even the seeming nature of the activities within this form of cooperation.

Phenomena of this type justify a more thought-out procedure of choosing foreign partners for cooperation, an example of which can be the Smart Integration project co-financed by the European Union with funding from the European Regional Development Fund in the INTERREG Poland-Saxony 2014-2020 Cooperation Programme. It should be emphasised that in the context of 17 agreements concluded with regions from 9 countries (not only European countries but also South American countries), the cooperation with Saxony has lasted the longest, as it was established on 17 September 1999. These were initially actions within the Phare CBC programme, in 2000-2006, the INTERREG III A Community Initiative Programme and in 2007-2013 the INTERREG IVC Programme. The project named 'Razem dla pogranicza Dolny Ślask - Saksonia'

33

34 Refer to the announcement of the Minister of Internal Affairs and Administration of 8 July 2002 on the list of territorial self-government units that joined international associations of local and regional communities in the period from 28 January 2001 to 14 February 2002, and the list of territorial self-government units that left international associations of local and regional communities in the period from 28 January 2001 to 14 February 2002 (MP No 32, item 502)

Resolution No XXXI/497/08 of the Lower Silesian Voivodship Assembly of 30 October 2008 regarding the withdrawal from the Association 'Dolny Sląsk w Unii Europejskiej' $<$ http://bip.umwd.dolnyslask.pl/dokument.php?iddok=2846> accessed 20 March 2018

Resolution No X/217/15 of the Lower Silesian Voivodship Assembly of 21 May 2015 on the withdrawal of the 'Lower Silesian Voivodeship from the Assembly of European Regions (AER)'<http://bip.umwd.dolnyslask.pl/dokument,iddok,28988,idmp,474,r,r> accessed 20 March 2018 
[Together for the Lower Silesia - Saxony borderland] project that was developed and implemented in the last of these periods, which was completed in 2015, received an award in the contest for model projects of Polish-German cooperation 2012-2013, organised by the Ministry of Infrastructure and Development and the Federal Ministry of Transport, Building and Urban Development. The high rating of the project as a platform for an exchange of knowledge and experience between the Lower Silesian and Saxony administrations determined that this was considered a model project of cooperation of administration from border regions. The thematic focus of the cooperation on the most important and problematic issues for both regions was taken into account. Encouraged by this effect of their activities, the project partners, especially the leaders of the working parties and representatives of the authorities of both regions, confirmed that there is a need for a new project in the 2014-2020 programming period, which would be based on the capitalisation of the results achieved in the completed project and also enabled the further development of the discussions around the transfrontier challenges and problem areas that, in the opinion of the Polish and German participants of the working parties, deserve a deeper and more detailed examination.

Since February 2017, the Lower Silesian Voivodeship, together with the Saxony Ministry for Internal Affairs, has been implementing the Smart Integration ${ }^{37}$ project within the transfrontier INTERREG Poland - Saxony 20142020 cooperation programme. The leading partner in the project is the Saxony Ministry for Internal Affairs, whilst the project partners are the Marshal Office of the Lower Silesian Voivodeship and the Institute for Territorial Development. ${ }^{38}$ The main objective of the Smart Integration Project is to intensify and strengthen the administrative activities in regional and spatial development on both sides of the border, contributing to the improvement in the living conditions of the population and the sustainable development of the Lower Silesian-Saxony border area. Specific objectives are distinguished in it: 1) the development of assumptions and strategic solutions, as well as the identification of potentials regarding joint transfrontier spatial and regional development in the area of support, 2) the development and implementation of measures leading to the minimisation of the

37 The partnership agreement in the Smart Integration project was signed on 17 March 2017 in the Marshal Office of the Lower Silesian Voivodship, after which the first meetings of the project team were held on 16-17 March 2017, the subject of which was the discussion of the schedule of events for $2017<$ https://www.irt.wroc.pl/aktualnosc-32-430-umowa partnerska_w_ramach_projektu.html $>$ accessed 20 March 2018

The self-government organisational unit of the Lower Silesian Voivodeship emerged from the transformation of the Voivodeship Urban Planning Office. Its objectives include the fulfilment of Voivodeship tasks with regard to the development and spatial planning policy. In its implementation, the Smart Integration project plays the role of the second partner, although, in fact, its involvement is crucial, given the topic of demographics, economics and spatial challenges for the integration of both regions, which are dominant in the project 
effects of demographic changes amongst the Saxony-Lower Silesian borderland population and 3) the support of the development of the regional identity of the Saxony-Lower Silesian borderland. The negative factors of borderland development arising from its peripheral nature have a negative impact on the choice of such objectives, because of the substantial distance from the main centres of the Lower Silesian, Lubuskie and Saxony regions. Because their multifaceted impact on the socio-economic sphere is felt on both sides of the border, action needs to be taken with regard to spatial and regional development in the transfrontier dimension, all the more so that joint transfrontier studies with a similar thematic scope have not been developed to date. Therefore, only a smart approach to close cooperation between institutions responsible for these areas of support in each region can integrate them in a common solution to their common problems.

Such integration is to be enabled by the Smart Integration project, as despite a formally existing system of institutional planning arrangements, ${ }^{39}$ a common support system for spatial and socio-economic development does not operate in Saxony and Lower Silesia. On the one hand, it generates barriers to development and, on the other hand, it hinders their combating and limits the ability to develop common solutions.

Two transfrontier studies are planned to contribute directly to the implementation of the Polish-German Intergovernmental Commission guidelines as part of the first detailed objective. These studies are the Socio-Economic Analysis of the Lower Silesia-Saxony Borderland containing a diagnosis of the whole of the area of support and the Saxony-Lower Silesian Borderland Study presenting practical solutions. Furthermore, a joint Expert Commission supporting the development of both documents took up activities in the project structures. ${ }^{40}$

39 They arise from international agreements, especially in the area of protection of the transfrontier landscape from art 10 of the European Landscape Convention drawn up in Florence on 20 October 2000 (Journal of Laws from 2006, No 14, item 98), public participation in decision-making regarding specific projects that can affect the environment under art 6 of the Aarhus Convention on access to information, public participation in decision-making and access to justice in environmental issues in the EU Convention drawn up on 25 June 1998 (Journal of Laws of 2003, No 78, item 706), as well as the Geneva Convention on LongRange Transboundary Air Pollution of 13 November 1979 (Journal of Laws of 1985, No 60, item 31 , as amended)

40 The next meeting was held on 7-8 December 2017 in Dresden and was devoted to the assessments of the first achievements in the project, its weaknesses and achievements, as well as the plans for 2018 (Bericht 2. Treffen des Projektteams), <http://landesentwicklung. sachsen. de/29534.htm> accessed 30 May 2018; during the meeting in Zgorzelec on 20 April 2018, a typology and a delimitation of the functional areas in the Spatial Development Plan of the Lower Silesian Voivodeship were presented, which are to be used in the further work on the Socio-Economic Analysis of the Lower Silesian-Saxony Borderland; while on 28 May 2018, thematic maps, being an integral part of the future Border Study, were analysed at the Marienthal monastery in Ostritz <http://www.umwd.dolnyslask.pl/rozwoj/smartintegration/> accessed 20 June 2018 
Entities from the support area are consulted on an on-going basis on the resulting documents at forums specially organised for this purpose. ${ }^{41}$ The Expert Committee held its first meeting in the Polish support area in Bolesławiec on 29 June 2017, setting the rules for further action (parallel work of a team of Polish experts and a team of Saxony experts on their areas of support with an on-going exchange of materials in order to standardise the documentation and a series of workshops), as well as three thematic areas for future analysis: 1) demographic and social challenges, 2) economic challenges and 3) spatial challenges. It was also assumed that two sub-regions would be separated within the project on the Polish side (the Jelenia Góra sub-region in the Lower Silesian Voivodeship and Żarski County in the Lubuskie Voivodeship) as well as two sub-regions on the German side (Görlitz county and Bautzen county) where negative demographic and economic changes are focusing. ${ }^{42}$

Within the framework of the second objective, the need was first assumed to diagnose the demographic state of the support areas arising from processes that are typical of them (e.g. depopulation of small towns, the ageing of the population, the disproportion of the gender structure in terms of numbers) as well as those only appearing on the German side (inflow of immigrants) and, on this basis, through workshop work with experts, variants of solutions were presented, which had the objective of neutralising the negative consequences of these processes (e.g. for access to public services and the organisation of emergency medical services), weakening its pace and even - in the longer term - reversing its trend. ${ }^{43}$

41 The latest Forum was held on 21 June 2018 and was devoted to the presentation of the results of the partial Saxony-Lower Silesian Borderland Study <http://www.umwd.dolnyslask.pl/ rozwoj/smart-integration/aktualnosci/> accessed 25 June 2018

42 So far, meetings were held on 29 September 2017 in Schrigiswalde-Kirschau devoted to methodological arrangements (1. Sitzung der Expertenkomission Sächsisch-Niederschlesische Grenzraumstudie); during the second meeting on 27 February 2018, Bautzen dealt with the results of the study by 'INFRASTRUKTUR \& UMWELT Professor Böhm und Partner' regarding areas of operation of the settlement structures and centres, their directions, construction and long-term growth (Bericht 2. Sitzung der Expertenkomission SächsischNiederschlesische Grenzraumstudie)

43 Four workshops were held within this objective: on 28 November 2017, in Jelenia Góra, devoted to the ageing of society in the transfrontier area and the adaptation of public services and healthcare to this phenomenon (Bericht 1. Expertenwerkstatt Demografie); 12 December 2017 in Bautzen, devoted to the migration of the population aged up to 40 from small towns to large urban centres, for example, Dresden, etc. (Bericht 2. Expertenwerkstatt Demografie) and on 5 April 2018 in Bertsdorf-Althörnitz devoted to the typification of small- and mediumsized towns and the related conditions in their social policy, as well as the stabilisation of demographic processes(Bericht3. ExpertenwerkstattDemografie), $<$ http://landesentwicklung. sachsen.de/29534.htm> accessed 30 May 2018. The last, fourth workshop, which was held in Dobków on 24 April 2018, had the purpose of summarising expert work in determining the scale of changes in the demographic structure of the population in the borderlands, the process shaping it and the increasingly dangerous depopulation, as well as the presentation of an urban policy proposal on this, emphasising the softening of competition between individual cities in favour of the growing cooperation between them, <http://www.umwd.dolnyslask.pl/ rozwoj/smart-integration/aktualnosci/> accessed 20 June 2018 
The possibility of implementing proven solutions from other borderlands, where such phenomena had taken place earlier and where actions had been successfully taken, is being considered.

Finally, the third objective of the Smart Integration project is to be targeted directly at the support area communities; their local structures, not only related to the bodies of local administration (e.g. the authorities of the borderland municipalities); and also social organisations, associations, local initiative groups and so on. It is supposed to serve the purposes of getting to know each other better and enabling direct contacts arising from being aware of the neighbourhood and the natural need for day-to-day meetings and joint activities without institutional inspiration. In order to enable the achievement of this project's objective, workshops will be organised for local, regional and supra-regional media, during which the information about the Saxony-Polish borderland, its everyday life and development opportunities will be presented, in the hope that the media message will support local activities. Meanwhile, language courses will be organized from the support area for the inhabitants of the locations themselves (Polish for the Saxons, German for the Lower Silesians), as will study visits for school pupils, joint artistic events enabling them to present their activities and achievements in this field to each other. One of the projects under this measure is the reinforcement of the potential of rural communities by promoting the idea of creating and maintaining traditions in the form of thematic villages. ${ }^{44}$ Study visits will also be organised for the members of the bodies of the local authorities (councillors and mayors) and employees of local government administration employees, in order for them to better understand the organisational structures and the principles of functioning of Polish and German municipalities and counties. The activities undertaken within this objective include the Convention of Borderland Municipalities from Saxony and Lower Silesia, which was held on 15 May 2018, attended by 80 participants, including many mayors and heads of counties from both regions. ${ }^{45}$

44 Study visits were dedicated to this direction of implementation of the third objective of the project: 14-15 September 2017 in Obercunnersdorf, considered one of the Most Beautiful Villages of Saxony, to the thematic village 'Textildorf' - Großschönau, in the ecologicalcreative-Sorbian village Nebelschütz/Njebjelčicy; a visit organised for 29-30 May 2018 in the Lower Silesian support area at the village of Czaple (Leaders of the Sand and Stone Thematic Village), the Sudecka Zagroda Edukacyjna educational centre in Dobków, Chełmsko ('Tkacze Śląscy’ Association for the Development of Chełmsko Śląskie). <http:// www.umwd.dolnyslask.pl/ rozwoj/smart-integration/aktualnosci/> accessed 20 June 2018

Available at $<$ http://landesentwicklung.sachsen.de/29534.htm $>$ accessed 30 May 2018 


\section{ConCLusions}

Despite only being in its first phase of implementation, the Smart Integration project presented in the article justifies its assessment as an example of the smart action of the public administration towards smart integration of self-governments in the borderlands for the purpose of jointly solving problems that appear in this area regardless of their nationality. The essence of this assessment is a number of aspects that support the smart feature of these activities.

First of all, attention is drawn to the systemic nature and long time horizon of the planned activities. Therefore, they are not ad hoc activities, as is the case of many municipal cooperation initiatives, even transfrontier activities. An example may be that of partnership agreements intended to provide assistance in situations of crisis or natural disasters, which only seemingly have the feature of permanence, when in fact they apply to actions only taken at the time that the given state appears until it passes or its effects are removed. In the case in question, issues such as demographic processes and spatial development are essentially timeless, and therefore, even if the current financing period of project activities ends, their effects may have features of permanence, whilst the developed integration mechanisms can function without external inspiration, which is one of the main objectives of this project.

The project uses not only the knowledge resources of expert groups but also the knowledge of the members of local self-government authorities and the employees of borderland institutions. Expert knowledge is classically transferred to the practice of the functioning of these self-governments and their institutions. The project also assumes the mutual learning of co-existence by local communities on both sides of the border, the awareness of their identity as well as finding out about and respecting each other's identity. The possibility of the emergence of the phenomenon of a 'learning region' is emerging, albeit in a different version to that understood by the creator of this notion, Richard Florida, because these regions will almost certainly not attract the so-called 'creative class' ${ }^{46}$ but with a certain increase in public awareness, there may be a stoppage or even a reversal of the population migration trend (including, unfortunately, most frequently the groups with higher and the highest qualifications) from the areas of support to larger centres, which are usually a greater distance from the border between the countries as the main geographic reference point. It cannot be assumed that the borderland municipalities and the counties will become competition for the capitals of both regions of Dresden and Wrocław, although the Smart Integration of their residents can stop treating them as purely their birthplace, which is

46 cf Richard Florida, 'Toward the Learning Region' (1995) 27(5) Futures 
abandoned at a certain stage of life, after reaching a certain level of qualifications, for a vision of a better life in large urban agglomerations.

The project assumes the improvement of the transfrontier potentials of these areas and their mutual support in solving demographical, economical and spatial problems on an unprecedented scale and perspective of municipal cooperation. This is the fulfilment of a former idea of Robert Schuman, especially Jean Monet, who formulated the theory of small steps, namely gradual integration in small areas, emphasising that 'La coopération entre les nations, si importantes soit-elle, ne résout rien. Ce qu'il faut chercher, c'est une fusion des intérêts des peuples européens, et non pas simplement le maintien de l'équilibre de ces intérêts'. ${ }^{47}$

\section{Bibliography}

Boć Jan, 'Administracja publiczna jako organizacja inteligentna' in Boć J (ed), Administracja publiczna (Kolonia Limited, 2003)

Czarnow Stefan, 'Niektóre aspekty prawne współpracy transgranicznej i euroregionów’ in Państwo i Prawo (Wolters Kluwer, Polska 1997)

Czechowski Paweł and Niewiadomski Zygmunt, 'Administracyjno-prawne przesłanki komunalnej współpracy przygranicznej w Republiką Federalną Niemiec’ (1992) 16(1-2) Człowiek i Środowisko

Florida Richard, ‘Toward the Learning Region' (1995) 27(5) Futures

Gwizdała Jerzy P, ‘Euroregiony jako forma współpracy transgranicznej w Europie’ Zeszyty Naukowe Uniwersytetu Szczecińskiego (2015) 855 Finanse, Rynki Finansowe, Ubezpieczenie $74(2)$

Korczak Jerzy, 'Ewolucja form współdziałania jednostek samorządu terytorialnego na forum międzynarodowym' in Sługocki Janusz (ed), Samorzad terytorialny w Polsce $i$ Europie. Doświadczenia i dylematy dalszego rozwoju (Kujawy and Pomorze University in Bydgoszcz, Bydgoszcz 2009)

Korczak Jerzy, 'Priorytety współpracy zagranicznej województwa jako akt regionalnej polityki zagranicznej' in Seminar 'Regiony - między państwem a Europą. Modele porównawcze i perspektywy rozwoju' (Chamber of Crafts and Small and Medium-Sized Enterprises in Katowice, Katowice 2009)

Korczak Jerzy and Nowacki Konrad, 'Die kommunalen Verbänden und ihre Zusammenarbeit unter Berücksichtigung der grenzüberschreitenden Fragen ' in Eike Albrecht, Konrad Nowacki (Hrsg.), Die grenzüberschreitende Beteiligung der Öffentlichkeit und der Behörden in Deutschland und Polen (LexxionVerlagsgesellschaft mBh, Berlin 2006)

Łazutka Paulina, 'Współdziałanie gmin uzdrowiskowych w formie związku celowego jako przykład wielopostaciowości form wykonywania zadań z zakresu administracji publicznej’ in J Korczak, P Lisowski and E Pierzchała (eds), Wielopostaciowość wspótczesnej administracji publicznej. Publikacja poświęcona pamięci Pana Profesora Jana Bocia, 'Opolskie Studia Administracyjno-Prawne' 2018, No. XVI/1/1

47 Jean Monnet, Mémoires, l'Edition Fayard, Paris 1976, p. 371 
Kościuch Bogdan and Poźniak Anna, 'Euroregiony a współpraca zagraniczna jednostek samorządu terytorialnego', (2012) 12 Białostockie Studia Prawnicze

Kusiak-Winter Renata, Wspótpraca transgraniczna Polski $i$ Niemiec. Studium administracyjnoprawne (Digital Legal Library, Wrocław 2011)

Malarski Stanisław, Regiony $i$ euroregiony, zagadnienia organizacyjne, prawne, administracyjne (Opole 2003)

Monnet Jean, Mémoires (l`Edition Fayard, Paris 1976)

Pagenkopf Hans, Kommunalrecht. Bd. 1 (Carl Heymanns Verlag KG, Köln - Berlin - Bonn - München 1975)

Stachura Agnieszka, Sikora-Gaca Małgorzata, 'Działalność i zróżnicowanie euroregionów na terenie Polski’ (2015) XI Studia Gdańskie. Wizje i rzeczywistość 